\title{
Autonomous Mower vs. Rotary Mower: Effects on Turf Quality and Weed Control in Tall Fescue Lawn
}

\author{
Michel Pirchio ${ }^{1, *}$, Marco Fontanelli ${ }^{1}$, Christian Frasconi ${ }^{1}$, Luisa Martelloni ${ }^{1}$, \\ Michele Raffaelli ${ }^{1}$, Andrea Peruzzi ${ }^{1}$, Monica Gaetani ${ }^{1}$, Simone Magni ${ }^{1}$ (iD, Lisa Caturegli ${ }^{2}$, \\ Marco Volterrani ${ }^{1}$ and Nicola Grossi ${ }^{1}$ (10 \\ 1 Department of Agriculture, Food and Environment, University of Pisa, 56124 Pisa, Italy; \\ marco.fontanelli@unipi.it (M.F.); christian.frasconi@unipi.it (C.F.); lmartelloni@agr.unipi.it (L.M.); \\ michele.raffaelli@unipi.it (M.R.); andrea.peruzzi@unipi.it (A.P.); monica.gaetani@unipi.it (M.G.); \\ simone.magni@unipi.it (S.M.); marco.volterrani@unipi.it (M.V.), nicola.grossi@unipi.it (N.G.) \\ 2 Department of Agricultural Sciences, University of Bologna, 40127 Bologna, Italy; lcaturegli@gmail.com \\ * Correspondence: michel.pirchio@for.unipi.it; Tel.: +39-050-2218915
}

Received: 19 December 2017; Accepted: 3 February 2018; Published: 6 February 2018

\begin{abstract}
Autonomous mowers are battery-powered machines designed for lawn mowing that require very low human labour. Autonomous mowers can increase turf quality and reduce local noise and pollution compared with gasoline-powered rotary mowers. However, very little is known about the effects of autonomous mowing on encroaching weeds. The aim of this research was to compare the effects of an autonomous mower and an ordinary gasoline-powered mower on weed development in an artificially infested tall fescue (Festuca arundinacea Schreb.) turf with different nitrogen $(\mathrm{N})$ rates. A three-way factor experimental design with three replications was adopted. Factor A consisted of three $\mathrm{N}$ rates $\left(0,75\right.$, and $\left.150 \mathrm{~kg} \mathrm{ha}^{-1}\right)$, factor $\mathrm{B}$ consisted of two mowing systems (autonomous mower vs. walk-behind gasoline rotary mower equipped for mulching), and factor $\mathrm{C}$ which consisted of four different transplanted weed species: (a) Bellis perennis L., (b) Trifolium repens L.; (c) Trifolium subterraneum L.; and (d) Lotus corniculatus L. Of these, B. perennis is a rosette-type plant, while the other three species are creeping-type plants. The interaction between mowing system and transplanted weed species showed that the four transplanted weed species were larger when mowed by the autonomous mower than by the rotary mower. The autonomous mower yielded larger weeds probably because the constant mowing height caused the creeping weed species to grow sideways, since the turfgrass offered no competition for light. $\mathrm{N}$ fertilization increased turf quality and mowing quality, and also reduced spontaneous weed infestation. Autonomous mowing increased turf quality, mowing quality, but also the percentage of spontaneous weed cover.
\end{abstract}

Keywords: Festuca arundinacea; energy saving; Trifolium spp.; Bellis spp.

\section{Introduction}

In Italy, the most widespread cool-season turfgrass is tall fescue (Festuca arundinacea Schreb.) [1]. Tall fescue is noted especially for its wear resistance, weed competition, shade tolerance, and deep root system. Compared to other cool season turfgrass species, tall fescue is the most resistant to drought, high temperatures, and salinity [2]. For sports turf applications, tall fescue is not commonly used, since it has difficulty withstanding low mowing heights [3] and its leaves tend to partially wither in winter [4]. Burns [5] revealed how tall fescue is affected by mowing height, showing that the best quality was achieved at heights ranging from 2.5 to $4 \mathrm{~cm}$. In addition, several authors have studied dwarf-type tall fescue cultivars selected to withstand low mowing. Based on the lower growth rate of these cultivars, appropriate levels of fertilization and mowing are required [6-8]. Grossi et al. [9] studied the effects of low mowing height (ranging from $1.0 \mathrm{~cm}$ to $2.5 \mathrm{~cm}$ ) on two 
cultivars of tall fescue. The highest quality was achieved with the lowest mowing height, proving that tall fescue cultivars selected to withstand low mowing heights are suitable for sports turf applications. Dernoeden et al. [4] studied the effects of mowing, nitrogen fertilization, and herbicides on the weed management of tall fescue turf. The two main species of weeds found in tall fescue turf were crabgrass (Digitaria ischaemum Schreb.) and white clover (Trifolium repens L.). Herbicides were effective in controlling weed populations, irrespective of nitrogen fertilization. High mowing $(8.8 \mathrm{~cm})$ was the best cultural management for reducing crabgrass infestation. Mowing at lower heights $(3.2$ and $5.5 \mathrm{~cm})$ led to higher crabgrass infestation. White clover, on the other hand, was more competitive as the tall fescue height increased. In contrast, Burns [10] observed a larger infestation of white clover in tall fescue mowed at $4.0 \mathrm{~cm}$ compared to tall fescue mowed at $8.0 \mathrm{~cm}$. Burns also found that tall fescue density was higher after three years when mowed at $8.0 \mathrm{~cm}$. Turf mowing originally required human labour. The height and frequency of mowing were performed in order to respect the " $1 / 3$ rule", which means that mowing does not involve more than one third of the total height of the grass, in order to prevent scalping and physiological stress [11]. The most widespread lawnmowers in Italy are electric rotary mowers for small gardens and gasoline-powered rotary mowers for larger gardens [12]. However, autonomous mowers are becoming more common. The first autonomous mower was produced in 1995 by Husqvarna, a Swedish company, and was powered by solar energy. Current autonomous mowers are battery-powered machines that autonomously perform turfgrass mowing. Autonomous mowers usually move randomly within a precise perimeter for a predetermined period of time. The perimeter is defined by a shallow-buried boundary wire which generates an electro-magnetic field. Once the autonomous mower reaches the boundary wire or an obstacle, it stops and changes direction. However, autonomous mowers do not know which areas have or have not been cut. Given a sufficient time interval, the autonomous mower is likely to cut most of the lawn [13]. It is an effective solution to cover areas with many obstacles, but leads to frequent overlapping [14]. There are various alternative ways to prevent mowing overlap. Chandler [13] developed a texture-based vision system to enable the autonomous mower to detect where the grass has already been cut. The working capacity of autonomous mowers designed for private or industrial areas ranges from 400 to $5000 \mathrm{~m}^{2}$. The largest autonomous mowers can manage up to $30,000 \mathrm{~m}^{2}[15,16]$. To prevent mowing overlap, autonomous mowers working on large areas can be equipped with a GPS which provides a "random assisted" pattern [17] or with differential GPSs for systematic trajectories [16]. Autonomous mowers can be equipped with razor-like pivoting blades mounted on a cutting disc $[17,18]$ or with solid blades, with three or four cutting edges [16,19]. Autonomous mowers have several advantages. Firstly, although autonomous lawn mowers do not replace humans managing turfgrass (professionals or just lawn owners), they help to save a great amount of time. Time saving enables the person managing the turf to have time for other turf management operations or simply for other purposes. Not having to mow the turf also prevents humans from coming into contact with dust, allergens, polluting gasses (if the engine is a gasoline engine), and noise [14,20]. Secondly, autonomous mowers do not produce polluting gasses or dust. Thirdly, they are so silent that they can perform the mowing even at night. Fourthly, given that autonomous mowers are usually programmed to operate every day, the clippings are very small and are left in place. Autonomous mowers do not collect clippings, which become integrated into the turf and thus recycling nutrients. This process is called "grasscycling". Grasscycling leads to a higher turf quality, lower weed percentage, lower need for nitrogen fertilization, and does not contribute to the formation of thatch [21]. However, there are some differences between the effects of autonomous mower clippings and ordinary mulching rotary mower clippings. Ordinary walk-behind rotary mowers are usually used following the " $1 / 3$ rule". Clippings from ordinary walk-behind rotary mowers are generally larger than clippings from autonomous mowers. Macolino and Ziliotto [22] observed that ordinary rotary mower clipping release in tall fescue led to a severe reduction of root density and root length, losing up to $45 \%$ of total root weight. Ferguson and Newell [23] observed the effects of the autonomous mower, Bigmow, compared to a reel mower. Turf mowed by Bigmow had a lower disease incidence and lower broad-leaved weed infestation. In some studies on Poa pratensis L. 
and F. arundinacea Schreb. [24-26], mulching has increased turf quality compared to mowing with clipping removal. Mulching also improved turf colour in the autumn and winter, and did not lead to any variation in thatch thickness. Grossi et al. [27] compared the effects of mulching and mowing with clipping removal in a tall fescue turf. Turf quality and turf colour were higher when mulching was performed. Thatch was not influenced by the mowing system. Weed control is an important task in turf management. Weeds can greatly reduce turf quality. Any stress factor that reduces turfgrass cover, such as poor management practices, disease, or extreme environmental conditions, can result in weed infestation. As previously mentioned, weed control in turfgrass over the years has mainly been performed with chemical herbicides. However, the use of chemical herbicides has been increasingly restricted because of their highly negative impact on the environment and on human health. The trend is to find alternative solutions for weed control in turfgrass based on management practices in order to reduce the use of chemical active ingredients. To date, very little is known about the effects of autonomous mowers on weed control. The main purpose of this trial was to compare the effects of an autonomous mower, an ordinary gasoline-powered mower, and nitrogen $(\mathrm{N})$ fertilization rates on weed development in an artificially infested tall fescue (Festuca arundinacea Schreb.) turf. The trial was carried out to simulate the spontaneous weed infestation of a cool-season turf with different nitrogen (N) levels, and to evaluate the turf quality and energy consumption of the two mowing systems.

\section{Materials and Methods}

The experimental trial was carried out in S. Piero a Grado, Pisa $\left(43^{\circ} 39^{\prime} \mathrm{N} 10^{\circ} 21^{\prime}\right.$ E, $5 \mathrm{~m}$ a.s.l.) from April to October 2016 on a two-year old stand of Festuca arundinacea cv 'Arminda', established in a soil characterized by the following physical-chemical properties: $91 \%$ sand, $5 \%$ silt, $4 \%$ clay, $\mathrm{pH} 6.6$, $1.4 \mathrm{~g} \mathrm{~kg}^{-1}$ of organic matter; EC $0.51 \mathrm{dS} \mathrm{m}{ }^{-1}$. On 23 March 2016, fertilization with $30 \mathrm{~kg} \mathrm{ha}^{-1}$ of P (superphosphate) and $100 \mathrm{~kg} \mathrm{ha}^{-1}$ of $\mathrm{K}$ (potassium sulphate) was applied. Irrigation was applied as necessary to prevent wilt turf.

The trial started on 20 April 2016. A three-way factor experimental design $(A \times B \times C)$ was adopted. The entire area was $1404 \mathrm{~m}^{2}(54 \times 26 \mathrm{~m})$ subdivided in three randomized blocks of $468 \mathrm{~m}^{2}$ $(18.0 \times 26.0 \mathrm{~m})$ each.

Factor (A) consisted in 3 levels of nitrogen fertilization delivered in one application: $(0,75$, and $150 \mathrm{~kg} \mathrm{ha}^{-1}$ of $\mathrm{N}$ (ammonium sulphate 21-0-0).

Factor (B) consisted in 2 mowing systems: (1) autonomous mowing with a Husqvarna Automower mod. 420 set $8 \mathrm{~h}$ day ${ }^{-1}$ working time, and (2) manual mowing (once a week) with a walk-behind gasoline rotary mower Honda mod. HRD 536 HX (Honda France Manufacturing, Ormes, France), equipped for mulching. The six sub-plots were $234 \mathrm{~m}^{2}(18.0 \times 13.0 \mathrm{~m})$ each.

Factor (C) consisted in four different transplanted weed species. In 2015, seeds of local weed ecotypes were collected. The four species selected for transplantation were: (a) Bellis perennis L.; (b) Trifolium repens L.; (c) Trifolium subterraneum L.; and (d) Lotus corniculatus L. B. perennis is a rosette-type plant, while the other three species are creeping-type plants. Young plants were obtained from the local ecotype seeds and raised in peat-filled honeycomb alveoli. Peat volume available for each plant was $5 \mathrm{~cm}^{3}$. At the time of transplant, plants were 3 to $5 \mathrm{~cm}$ high and had never been trimmed down. Plants were manually transplanted in 4 rows of 6 plants $\mathrm{m}^{-2}$ (each plant was $0.40 \mathrm{~m} \times 0.25 \mathrm{~m}$ apart). Sub-sub-plots were 72. Each sub-sub-plot was $19.5 \mathrm{~m}^{2}(6.0 \times 3.25 \mathrm{~m})$. Only one weed species was transplanted on each sub-sub-plot.

Both mowers were set at a $3 \mathrm{~cm}$ mowing height. The blades of the rotary mower were sharpened every two weeks. The blades of the autonomous mower were replaced every two weeks. The Husqvarna Automower 420 is equipped with two pivoting front wheels and two course treaded rear driving wheels. Automower 420 has a $24 \mathrm{~cm}$-wide cutting disc with three small pivoting blades mounted on the disc for easy changing. Cutting height ranges from $2.0 \mathrm{~cm}$ to $6.0 \mathrm{~cm}$. Each rear wheel is powered by a brushless electric motor, and a third brushless electric motor drives the cutting disc. Maximum working capacity is $2200 \mathrm{~m}^{2}$ for a $24 \mathrm{~h} \mathrm{~d}^{-1}$ working time. The Honda HRD $536 \mathrm{HX}$ is 
a self-propelled rotary mower. It is equipped with mulching blades and with a hydrostatic drive for speed variation from 0 to $4.7 \mathrm{~km} \mathrm{~h}^{-1}$. The working width is $53 \mathrm{~cm}$. Cutting height ranges from $1.4 \mathrm{~cm}$ to $7.6 \mathrm{~cm}$. The power is generated by a $2.7 \mathrm{~kW}$ single cylinder gasoline four stroke combustion engine with an overhead camshaft. Engine displacement is $160 \mathrm{~cm}^{3}$.

For a 32-week period from 20 April to 24 November, the following parameters were assessed weekly:

- turf quality: ( 1 = poor; 9 = excellent), 6 = acceptable (Morris and Shearman, 2014);

- mowing quality: ( 1 = unevenly cut edge of leaf blade; 9 = perfectly cut edge of leaf blade), 6 = acceptable;

- disease: ( $1=100 \%$ injury; $9=0 \%$ injury) (Morris and Shearman, 2014);

- $\quad$ weed cover (\%): expressed as weed percentage of total ground cover;

- transplanted weed size: measured maximum diameter of each weed with ruler and data reported as $\mathrm{cm}$;

- rotary mower fuel consumption and Automower electricity consumption.

At $32 \mathrm{WAT}$, a single $50 \mathrm{~cm}^{2}$ core sample per plot was collected and the following parameters were determined in relation to the tall fescue:

- leaf width: 20 fully expanded leaves per plot were measured with a precision Vernier caliper and data reported in millimetres;

- $\quad$ shoot density: direct counting with data reported as shoots $\mathrm{cm}^{-2}$.

Statistical analysis of biometric data was carried out with COSTAT 6.400 software (CoHort Software, Monterey, CA, USA). All data were analysed by three-way ANOVA. Before being analysed, percentage data was transformed using angular transformation (arcsine of the square root). An all-pairwise Fisher's least significant difference (LSD) test at the probability level of 0.05 was used to detect the differences between means.

From April to October, working speed, working time, turning time, working capacity, power requirement, electrical energy requirement, and gasoline consumption were assessed. A power consumption meter (EL-EPM02HQ; Nedis, MC's-Hertogenbosch, The Netherlands) was used to assess the electrical energy requirement. The gasoline tank was filled just before mowing. Gasoline consumption was measured by refuelling the tank after mowing. The following conversion factors were used to estimate primary energy consumption: $9.2 \mathrm{kWh} / \mathrm{L}$ of gasoline (Gupta, 2014) and 0.46 as efficiency of the Italian National Electric System (European Union, 2014). The cost of both machines was estimated by referring to the study area for a comparison. Both fixed costs (purchase and depreciation) and variable costs (labor and consumption due to the use of the machines) were estimated. Machine life for both machines was estimated to be 10 years. The purchase cost of the Automower 420 was 2721 euros. The purchase cost of the Honda HRD 536 HX was 1538 euros. Gasoline cost was 1.50 euros/L. Labor cost was 25 euros/h. The total working period per year was calculated as 210 days.

\section{Results}

There was no significant 3-order interaction between factors, however, there was a significant interaction between mowing system and transplanted weed species. For the other parameters, the effects of $\mathrm{N}$ fertilization and mowing system (except for turf disease) were statistically significant $(p<0.05)$ (Table 1$)$. 
Table 1. Results of analysis of variance testing the effects of $\mathrm{N}$ rates, Mowing system, Transplanted weed species, and their interactions on Turf quality $(8,16,24$, and 32 weeks after treatment (WAT)), Mowing quality $(8,16,24$, and 32 WAT), Turf disease $(8,16,24$, and 32 WAT), Spontaneous weed cover percentage $(8,16,24$, and 32 WAT), Transplanted weed size $(8,16,24$, and 32 WAT), Leaf width (32 WAT) and Shoot density (32 WAT)

\begin{tabular}{|c|c|c|c|c|c|c|}
\hline Parameter & N Rates (A) & Mowing System (B) & Transpl. Weed Species (C) & (A) $\times($ B) & (B) $\times(C)$ & $(A) \times(B) \times(C)$ \\
\hline Turf quality (8 WAT) & * & * & ns & ns & ns & ns \\
\hline Turf quality (16 WAT) & * & * & ns & ns & ns & ns \\
\hline Turf quality (24 WAT) & * & * & ns & ns & ns & ns \\
\hline Turf quality (32 WAT) & * & * & ns & ns & ns & ns \\
\hline Mowing quality (8 WAT) & * & * & ns & ns & ns & ns \\
\hline Mowing quality (16 WAT) & * & * & ns & ns & ns & ns \\
\hline Mowing quality (24 WAT) & * & * & ns & ns & ns & ns \\
\hline Mowing quality (32 WAT) & * & * & ns & ns & ns & ns \\
\hline Disease (8 WAT) & ns & ns & ns & ns & ns & ns \\
\hline Disease (16 WAT) & * & ns & ns & ns & ns & ns \\
\hline Disease (24 WAT) & * & ns & ns & ns & ns & ns \\
\hline Disease (32 WAT) & ns & ns & ns & ns & ns & ns \\
\hline Weed cover (8 WAT) & * & * & ns & ns & ns & ns \\
\hline Weed cover (16 WAT) & * & * & ns & ns & ns & ns \\
\hline Weed cover ( 24 WAT) & * & * & ns & ns & ns & ns \\
\hline Weed cover (32 WAT) & * & * & ns & ns & ns & ns \\
\hline Transplanted weed size (8 WAT) & ns & * & * & ns & * & ns \\
\hline Transplanted weed size (16 WAT) & ns & * & * & ns & * & ns \\
\hline Transplanted weed size (24 WAT) & ns & * & * & ns & * & ns \\
\hline Transplplanted weed size (32 WAT) & ns & * & * & ns & * & ns \\
\hline Leaf width (32 WAT) & * & * & ns & ns & ns & ns \\
\hline Shoot density (32 WAT) & * & * & ns & ns & ns & ns \\
\hline
\end{tabular}

$*=p<0.05$. ns $=$ not significant. 
The interaction between mowing system and transplanted weed species at 8 weeks after treatment (WAT) showed that the mean diameter values of the four transplanted weed species were significantly larger when mowed by the autonomous mower rather than by the rotary mower (Table 2). At 16 WAT, diameter values of the four weed species mowed by the autonomous mower were still significantly larger than diameter values of the same weed species mowed by the rotary mower (Table 2). At 24 WAT, weed diameter values continued to be significantly larger when mowed by the autonomous mower than by the rotary mower (Table 2). T. repens reached a diameter of $12.5 \mathrm{~cm}$ when mowed by the autonomous mower vs. $6.8 \mathrm{~cm}$ when mowed by the rotary mower. At 32 WAT, weed diameter values were significantly larger when mowed by the autonomous mower than by the rotary mower (Table 2). T. repens reached a diameter of $24.0 \mathrm{~cm}$ when mowed by the autonomous mower vs. $7.0 \mathrm{~cm}$ when mowed by the rotary mower. L. corniculatus reached a diameter of $14.2 \mathrm{~cm}$ when mowed by the autonomous mower vs. $8.3 \mathrm{~cm}$ when mowed by the rotary mower.

Table 2. Mowing system and transplanted weed species interaction effect on weed diameter $(\mathrm{cm})$ after $8,16,24$, and 32 weeks of treatment. LSD, least significant difference.

\begin{tabular}{|c|c|c|c|c|}
\hline \multicolumn{5}{|c|}{8 Weeks after Treatment } \\
\hline Weed diameter $(\mathrm{cm})$ & Bellis perennis & Trifolium repens & Trifolium subterraneum & Lotus corniculatus \\
\hline Autonomous mower & 4.7 & 7.4 & 11.0 & 6.4 \\
\hline Rotary mower & 3.7 & 5.1 & 7.9 & 4.4 \\
\hline LSD 0.05 & \multicolumn{4}{|c|}{0.7} \\
\hline \multicolumn{5}{|c|}{16 Weeks after Treatment } \\
\hline Weed diameter $(\mathrm{cm})$ & Bellis perennis & Trifolium repens & Trifolium subterraneum & Lotus corniculatus \\
\hline Autonomous mower & 5.4 & 10.0 & 9.4 & 8.7 \\
\hline Rotary mower & 4.0 & 5.5 & 5.9 & 4.6 \\
\hline LSD 0.05 & \multicolumn{4}{|c|}{0.8} \\
\hline \multicolumn{5}{|c|}{24 Weeks after Treatment } \\
\hline Weed diameter $(\mathrm{cm})$ & Bellis perennis & Trifolium repens & Trifolium subterraneum & Lotus corniculatus \\
\hline Autonomous mower & 5.9 & 12.5 & 8.0 & 10.1 \\
\hline Rotary mower & 4.2 & 6.8 & 4.9 & 5.7 \\
\hline LSD 0.05 & \multicolumn{4}{|c|}{1.0} \\
\hline \multicolumn{5}{|c|}{32 Weeks after Treatment } \\
\hline Weed diameter $(\mathrm{cm})$ & Bellis perennis & Trifolium repens & Trifolium subterraneum & Lotus corniculatus \\
\hline Autonomous mower & 6.6 & 24.0 & 7.3 & 14.2 \\
\hline Rotary mower & 4.3 & 7.0 & 4.8 & 8.3 \\
\hline LSD 0.05 & & & 2.2 & \\
\hline
\end{tabular}

At 8 WAT, all doses of $\mathrm{N}$ fertilization improved turf quality values, compared to the unacceptable control value (4.7) (Table 3). Mowing quality was improved only with the higher dose of N. Turf disease was not affected by $\mathrm{N}$ fertilization. Spontaneous weed cover percentage decreased with higher $\mathrm{N}$ doses $(5.0 \%)$ vs. the control $(9.7 \%)$.

At 8 WAT, differences between the two mowing systems were also observed (Table 4 ). Turf quality and especially mowing quality were higher for the autonomous mower (5.8 and 7.6, respectively) compared to the rotary mower (5.5 and 6.9, respectively). Spontaneous weed cover percentage increased with the autonomous mower $(8.4 \%)$ compared to the rotary mower $(6.1 \%)$. 
Table 3. Nitrogen fertilization mean effect on tall fescue turf quality $(1=$ poor, $9=$ excellent), mowing quality ( $1=$ poor, $9=$ excellent), turf disease $(1=100 \%$ injury; $9=0 \%$ injury), and weed cover $(\%)$ after $8,16,24$, and 32 weeks of treatment.

\begin{tabular}{|c|c|c|c|c|}
\hline \multicolumn{5}{|c|}{8 Weeks after Treatment } \\
\hline $\mathrm{N}$ fertilization $\left(\mathrm{kg} \mathrm{ha}^{-1}\right)$ & Turf quality (1-9 scale) & Mowing quality (1-9 scale) & Turf disease (1-9 scale) & Weed cover $(\%)$ \\
\hline 0 & 4.7 & 7.2 & 9.0 & 9.7 \\
\hline 75 & 5.8 & 7.1 & 9.0 & 7.2 \\
\hline 150 & 6.6 & 7.5 & 9.0 & 5.0 \\
\hline LSD 0.05 & 0.4 & 0.2 & ns & 1.2 \\
\hline \multicolumn{5}{|c|}{16 Weeks after Treatment } \\
\hline $\mathrm{N}$ fertilization $\left(\mathrm{kg} \mathrm{ha}^{-1}\right)$ & Turf quality (1-9 scale) & Mowing quality (1-9 scale) & Turf disease (1-9 scale) & Weed cover $(\%)$ \\
\hline 0 & 5.5 & 7.0 & 7.8 & 15.2 \\
\hline 75 & 6.9 & 7.0 & 8.5 & 8.7 \\
\hline 150 & 7.5 & 7.1 & 8.8 & 6.3 \\
\hline LSD 0.05 & 0.4 & 0.1 & 0.3 & 2.2 \\
\hline \multicolumn{5}{|c|}{24 Weeks after Treatment } \\
\hline $\mathrm{N}$ fertilization $\left(\mathrm{kg} \mathrm{ha}^{-1}\right)$ & Turf quality (1-9 scale) & Mowing quality (1-9 scale) & Turf disease (1-9 scale) & Weed cover $(\%)$ \\
\hline 0 & 5.4 & 6.1 & 8.7 & 20.0 \\
\hline 75 & 6.8 & 6.5 & 9.0 & 13.5 \\
\hline 150 & 7.8 & 6.5 & 9.0 & 9.0 \\
\hline LSD 0.05 & 0.3 & 0.2 & 0.2 & 3.7 \\
\hline \multicolumn{5}{|c|}{32 Weeks after Treatment } \\
\hline $\mathrm{N}$ fertilization $\left(\mathrm{kg} \mathrm{ha}^{-1}\right)$ & Turf quality (1-9 scale) & Mowing quality (1-9 scale) & Turf disease (1-9 scale) & Weed cover $(\%)$ \\
\hline 0 & 5.4 & 6.5 & 8.5 & 15.7 \\
\hline 75 & 6.6 & 6.8 & 9.0 & 9.3 \\
\hline 150 & 7.4 & 6.8 & 9.0 & 4.3 \\
\hline LSD 0.05 & 0.4 & 0.2 & ns & 2.4 \\
\hline
\end{tabular}

Table 4. Mowing system mean effect on tall fescue turf quality $(1=$ poor, $9=$ excellent $)$, mowing quality ( 1 = poor, 9 = excellent), and weed cover (\%) after $8,16,24$, and 32 weeks of treatment.

\begin{tabular}{|c|c|c|c|}
\hline \multicolumn{4}{|c|}{8 Weeks after Treatment } \\
\hline Mowing system & Turf quality (1-9 scale) & Mowing quality (1-9 scale) & Weed cover $(\%)$ \\
\hline Autonomous mower & 5.8 & 7.6 & 8.4 \\
\hline Rotary mower & 5.5 & 6.9 & 6.1 \\
\hline LSD 0.05 & 0.3 & 0.3 & 1.0 \\
\hline \multicolumn{4}{|c|}{16 Weeks after Treatment } \\
\hline Mowing system & Turf quality (1-9 scale) & Mowing quality (1-9 scale) & Weed cover $(\%)$ \\
\hline Autonomous mower & 6.6 & 7.3 & 11.1 \\
\hline Rotary mower & 6.5 & 6.7 & 9.0 \\
\hline LSD 0.05 & 0.1 & 0.2 & 1.8 \\
\hline \multicolumn{4}{|c|}{24 Weeks after Treatment } \\
\hline Mowing system & Turf quality (1-9 scale) & Mowing quality (1-9 scale) & Weed cover $(\%)$ \\
\hline Autonomous mower & 6.9 & 6.9 & 16.8 \\
\hline Rotary mower & 6.4 & 5.8 & 11.6 \\
\hline LSD 0.05 & 0.2 & 0.1 & 3.1 \\
\hline \multicolumn{4}{|c|}{32 Weeks after Treatment } \\
\hline Mowing system & Turf quality (1-9 scale) & Mowing quality (1-9 scale) & Weed cover $(\%)$ \\
\hline Autonomous mower & 6.6 & 7.2 & 11.7 \\
\hline Rotary mower & 6.3 & 6.2 & 7.9 \\
\hline LSD 0.05 & 0.2 & 0.1 & 2.0 \\
\hline
\end{tabular}


At 16 WAT, the turf quality control value was still unacceptable (5.5), but all doses of $\mathrm{N}$ increased turf quality values (Table 3). Mowing quality slightly increased only with the higher $\mathrm{N}$ dose, while turf disease decreased for all $\mathrm{N}$ doses. Spontaneous weed cover percentage decreased (ranging from $15.2 \%$ to $6.3 \%$ ) as $\mathrm{N}$ dose increased. Mowing systems also led to different results (Table 4). Turf and mowing quality were higher for the autonomous mower (6.6 and 7.3, respectively) compared to the rotary mower (6.5 and 6.7, respectively). Spontaneous weed cover percentage was lower for the rotary mower $(9 \%)$ compared to the autonomous mower $(11.1 \%)$. At $24 \mathrm{WAT}$, the turf quality control value continued to be unacceptable (5.4), however, turf quality greatly increased with $\mathrm{N}$ fertilization (Table 3). Mowing quality also increased with the $\mathrm{N}$ fertilization. Disease was slightly higher for the control (8.7) than for the $\mathrm{N}$ fertilized turf (9.0). Spontaneous weed cover percentage was very high for control plots (20.0\%), but decreased as the $\mathrm{N}$ dose increased $(9.0 \%)$. Mowing system showed some effects on turf quality since the autonomous mower increased the turf quality value compared to the rotary mower (6.9 vs. 6.4, respectively) (Table 4). Mowing quality increased with the autonomous mower vs. the rotary mower ( 6.9 vs. 5.8 ). Rotary mower reduced spontaneous weed cover percentage $(11.6 \%)$ compared to the autonomous mower $(16.8 \%)$. At $32 \mathrm{WAT}, \mathrm{N}$ fertilization increased turf quality, compared to the unacceptable control value (5.4) (Table 3). $\mathrm{N}$ fertilization also improved mowing quality (6.8) compared to the control value (6.5). Spontaneous weed cover percentage decreased greatly with increasing $\mathrm{N}$ doses $(4.3 \%)$, although the control was slightly lower compared to 24 WAT ( $15.7 \%$ vs. $20.0 \%$ ). Autonomous mowing improved turf quality (6.6) vs. rotary mowing (6.3) (Table 4). Mowing quality also improved with the autonomous mower (7.2) vs. the rotary mower (6.2). Spontaneous weed cover percentage was slightly lower than 24 WAT, however, rotary mowing resulted in a lower weed cover percentage $(7.9 \%)$ than autonomous mowing $(11.7 \%)$.

At the end of the trial (32 WAT), leaf width and shoot density were measured for each plot.

$\mathrm{N}$ fertilization had significant effects on leaf width (Table 5). Leaves were significantly wider after an $\mathrm{N}$ dose of $150 \mathrm{~kg} \mathrm{ha}^{-1}(0.22 \mathrm{~cm})$ compared to the control $(0.18 \mathrm{~cm})$ and an $\mathrm{N}$ dose $75 \mathrm{~kg} \mathrm{ha}^{-1}$ $(0.19 \mathrm{~cm})$.

Table 5. Nitrogen fertilization mean effect on tall fescue leaf width $(\mathrm{cm})$ and shoot density (shoots $\mathrm{cm}^{-2}$ ) after 32 weeks of treatment.

\begin{tabular}{ccc}
\hline N Fertilization $\left(\mathbf{k g ~ h a}^{-\mathbf{1}}\right)$ & Leaf Width $\mathbf{( c m )}$ & Shoot Density $\left(\mathbf{n}^{\circ} \mathbf{~ c m}^{-\mathbf{2}}\right)$ \\
\hline 0 & 0.18 & 2.6 \\
75 & 0.19 & 2.9 \\
150 & 0.22 & 3.2 \\
LSD 0.05 & 0.03 & 0.4 \\
\hline
\end{tabular}

Leaf width was significantly thinner when the turf was mowed by the autonomous mower $(0.16 \mathrm{~cm})$ compared to turfgrass mowed with the rotary mower $(0.23 \mathrm{~cm})$ (Table 6).

Table 6. Mowing system mean effect on tall fescue leaf width $(\mathrm{cm})$ and shoot density $\left(\mathrm{n}^{\circ} \mathrm{cm}^{-2}\right)$ after 32 weeks of treatment.

\begin{tabular}{ccc}
\hline Mowing System & Leaf Width $(\mathbf{c m})$ & Shoot Density $\left(\mathbf{n}^{\circ} \mathbf{c m}^{-\mathbf{2}}\right)$ \\
\hline Autonomous mower & 0.16 & 3.6 \\
Rotary mower & 0.23 & 2.2 \\
LSD 0.05 & 0.02 & 0.3 \\
\hline
\end{tabular}

$\mathrm{N}$ fertilization also had significant effects on shoot density (Table 5). Shoot density was significantly higher where an $\mathrm{N}$ dose of $150 \mathrm{~kg} \mathrm{ha}^{-1}$ was applied $\left(3.2\right.$ shoots $\left.\mathrm{cm}^{-2}\right)$ compared with the control $\left(2.6\right.$ shoots $\mathrm{cm}^{-2}$ ). No significant difference was observed comparing the $\mathrm{N}$ dose of $75 \mathrm{~kg} \mathrm{ha}^{-1}$ with the control. Shoot density was higher when turfgrass was mowed by the autonomous mower ( 3.6 shoots $\left.\mathrm{cm}^{-2}\right)$ compared to turfgrass mowed with the rotary mower $\left(2.2\right.$ shoots $\left.\mathrm{cm}^{-2}\right)$ (Table 6$)$. 


\section{Energy Consumption and Estimated Costs of the Mowing Systems}

The energy consumption and estimated costs of the autonomous mower and rotary mower are shown in Table 7 . The autonomous mower's operational time was set at $8 \mathrm{~h}$ day $^{-1}$, including both mowing time and charging time. Overall mowing time was $5.3 \mathrm{~h} \mathrm{~d}^{-1}$ ( $37.1 \mathrm{~h} /$ week) and charging time was $2.7 \mathrm{~h} \mathrm{day}^{-1}(18.9 \mathrm{~h} /$ week). Electric energy consumption was $1.37 \mathrm{kWh}$ per week, which corresponds to $2.98 \mathrm{kWh}$ of primary energy (energy from primary sources transformed into electric energy). The power requirement to operate the mowing disc was approximately $30 \mathrm{~W}$. The power required for the boundary wire was $96 \mathrm{Wh} \mathrm{day}^{-1}$. The boundary wire was operative for $24 \mathrm{~h} \mathrm{day}^{-1}$.

Table 7. Energy consumption and estimated costs of the autonomous mower and the rotary mower working on a surface of $702 \mathrm{~m}^{2}$ at a $3.0 \mathrm{~cm}$ mowing height.

\begin{tabular}{ccc}
\hline Parameter & Unit & Value \\
\hline Autonomous mower & & \\
Set daily working time (mowing and recharging) & $\mathrm{h} \mathrm{day}^{-1}$ & 8.00 \\
Daily mowing time (no recharging) & $\mathrm{h} \mathrm{day}^{-1}$ & 5.30 \\
Electric energy consumption per week & $\mathrm{kWh} /$ week & 1.37 \\
Primary energy consumption per week & $\mathrm{kWh} /$ week & 2.98 \\
$\quad$ Cost per week & euros/week & 14.37 \\
Rotary mower & & \\
Working speed & $\mathrm{km} \mathrm{h} \mathrm{h}^{-1}$ & 3.00 \\
Total operative time & $\mathrm{h} /$ week & 0.63 \\
Gasoline consumption & $\mathrm{L} /$ week & 0.50 \\
Primary energy consumption & $\mathrm{kWh} /$ week & 4.64 \\
Cost per week (including labor cost, 25 euros/h) & euros/week & 20.23 \\
\hline
\end{tabular}

The Honda walk-behind mulching rotary mower, manually operated once per week, covered the same area $\left(702 \mathrm{~m}^{2}\right)$ in $0.63 \mathrm{~h}$. The average working speed was $3 \mathrm{~km} \mathrm{~h}^{-1}$. Gasoline consumption was $0.50 \mathrm{~L} /$ week. Primary energy consumption was $4.64 \mathrm{kWh}$ (Table 7). Comparing the weekly management of the tall fescue turf with the two mowing systems, the autonomous mower required a longer mowing time than the rotary mower ( 37.1 vs. $0.63 \mathrm{~h} /$ week). However, the autonomous mower had a lower energy consumption $(2.98 \mathrm{vs}$. $4.64 \mathrm{kWh} /$ week). As for the estimated costs, the autonomous mower was cheaper than the rotary mower considering the ordinary labour cost in Italy (14.37 vs. 20.23 euros/week) (Table 7).

\section{Discussion}

Throughout the trial period, turf quality, mowing quality, disease, shoot density, and tall fescue leaf width were improved when the autonomous mower was used. This could be due to the high cutting frequency of the autonomous mower which led to a constant and lower average turf height throughout compared with the rotary mower. Grossi et al. [9] observed that tall fescue responded to a lower mowing height by increasing shoot density and reducing leaf width. $\mathrm{N}$ fertilization was effective in controlling the spontaneous weed cover (Table 1). A healthy turf with a higher density is more competitive against weed encroaching. Because of the shallow sandy soil, the non-fertilized plots showed an unacceptable turf quality and the turf was not competitive against weeds. A similar study was carried out by Dernoeden et al. [4], who found that $\mathrm{N}$ fertilization in tall fescue reduced the crabgrass cover percentage. However, the lower average turf height probably led to a higher spontaneous weed cover in plots mown by the autonomous mower. Dernoeden et al. [4] found that higher mowing was the best to control crabgrass infestation. Burns [10] also observed a higher cover percentage of white clover when tall fescue was mown at $4.0 \mathrm{~cm}$ compared to an $8.0 \mathrm{~cm}$ mowing height. In our study, three of the four species of weeds artificially transplanted were creeping species (T. repens L., T. subterraneum L., L. corniculatus L.). Artificially transplanted weeds were also larger 
when turf was managed by autonomous mower. This could also be due to the lower average turf height compared to the turf mown with the rotary mower, as observed by other authors $[4,10]$. In fact, apart from B. perennis, these creeping dicots were able to expand sideways below the mowing height without competing for light from the tall fescue turf, since turf height was kept constant by the autonomous mower. The transplanted weeds adapted their growth at a low height in order not to be cut by the autonomous mower. Where the turf was mown once a week by the rotary mower, weeds had to grow taller to compete for light with tall fescue because the turf height would increase after mowing. Thus, some of the weeds would grow above the mowing height and get cut by the rotary mower. The lower power requirement of the autonomous mower could depend on the very low power needed to perform mowing (average power required by the machine during mowing is $30 \mathrm{~W}$ ). In addition, the autonomous mower does not have to cut large amounts of grass because by working every day, it only cuts small clippings. Comparing the number of working hours and the power requirement, the autonomous mower was shown to be a more efficient machine. Brushless electric motors have an efficiency of $90 \%$. A small ordinary gasoline engine has an efficiency ranging from $20 \%$ to $25 \%$, although it uses primary energy, while the efficiency of the Italian National Electric System is $46 \%$. However, the primary energy consumption measured in this trial differs from that measured by Grossi et al. [12], who compared an Automower 330X and a John Deere walk-behind mulching rotary mower. The Automower required $4.80 \mathrm{kWh}$ /week of primary energy to cover $1296 \mathrm{~m}^{2}$, while the John Deere required $12.60 \mathrm{kWh} /$ week. In our trial, the Automower 420 required $2.98 \mathrm{kWh} /$ week of primary energy vs. 4.64 for the Honda HRD rotary mower. The smaller gap in primary energy requirement is probably due to the higher efficiency of the Honda HRD compared to the John Deere JS63, and to a lower efficiency of the Automower 420 compared to the Automower 330X. The Honda HRD is a recent model, while the John Deere JS63 has been on the market for considerably longer. The higher fuel consumption of the John Deere JS63 is also due to its larger and much more powerful engine compared to the Honda ( 5.0 vs. $2.7 \mathrm{~kW})$. The Automower $330 \mathrm{X}$ has a greater battery capacity than the Automower 420 (5.2 vs. $3.2 \mathrm{Ah}$ ). This means that the Automower 330X can be recharged less frequently (every 135 vs. $105 \mathrm{~min}$ for Automower 420). Whenever the autonomous mower needs to be recharged, it spends time and energy moving around searching for a signal to guide it to the charging station. The battery charging also has its own efficiency. Thus, a greater number of recharges leads to a slightly less efficient machine. Although the Honda HRD is cheaper than the Automower 420 (1538 vs. 2515 euros), the cost per week of the rotary mower is higher because of its higher energy consumption and requirement for human labour.

\section{Conclusions}

Compared to the non-fertilized plots, $\mathrm{N}$ fertilization improved turf quality, mowing quality, and turf health, as well as decreasing spontaneous weed cover percentage. Autonomous mowing improved the turf quality and mowing quality compared to the weekly rotary mowing. Autonomous mowing also led to a finer leaf width and to a higher shoot density of the tall fescue. Of the four transplanted weed species, at 32 WAT, the largest of all was T. repens, followed by L. corniculatus. The autonomous mower seemed to slightly favour weed infestation, and led to larger transplanted weeds. Creeping weeds can adapt to constant mowing and will grow sideways below the mowing height. To withstand weed expansion, the turf needs to be properly fertilized in order to be more competitive. In fact, when the $\mathrm{N}$ fertilization was higher and the autonomous mower was used, the weed cover percentage did not affect the turf quality, since scores were very high. A lawn that is mown once a week (as commonly happens with rotary mowers) looks neat and tidy after mowing, but not over the following days. Thus, despite possibly having a slightly larger creeping weed species, a lawn mowed by an autonomous mower will always have the optimal quality and appearance if properly fertilized. The autonomous mower worked silently and did not produce any dust or polluting gasses. It also improved energy saving and required significantly lower human labour than the rotary mower. This may be an important advantage for people who do not have the time or physical capacities 
to care for their lawn. The trial highlighted that autonomous mowing has several advantages both in terms of the turf quality and the time and energy saving, despite performing slightly less well in terms of controlling creeping weeds. Further research is needed to test the effects of autonomous mowers on vertically developing weeds and on turf quality at a taller mowing height.

Acknowledgments: We would sincerely like to thank FERCAD S.p.a. (Altavilla Vicentina, Vicenza, Italy) for providing the autonomous mower and technical assistance. We did not receive funds for this research. This research was supported by University of Pisa, project, "Advanced technologies for an environmentally eco-friendly management of turfgrass" ("Progetti di Ricerca di Ateneo 2016").

Author Contributions: M.P., M.F., C.F., L.M., M.R., A.P., M.G., S.M., L.C., M.V., N.G. conceived and designed the experiments, performed the experiments, analyzed the data, contributed analysis tools and wrote the paper.

Conflicts of Interest: The authors declare no conflict of interest.

\section{References}

1. Volterrani, M.; Magni, S. Species and growing media for sports turfs in Mediterranean area. Acta Hortic. 2004, 661, 359-364. [CrossRef]

2. Huang, B.; Gao, H. Root physiological characteristics associated with drought resistance in tall fescue cultivars. Crop Sci. 2000, 40, 196-203. [CrossRef]

3. Moore, R.W.; Christians, N.E. Tall Fescue Management Study; Iowa Turfgrass Research Report; Iowa State University: Ames, IA, USA, 1989; pp. 28-29.

4. Dernoeden, P.H.; Carroll, M.J.; Krouse, J.M. Weed management and tall fescue quality as influenced by mowing, nitrogen, and herbicides. Crop Sci. 1993, 33, 1055-1061. [CrossRef]

5. Burns, R.E. Tall Fescue Turf as Affected by Mowing Height. Agron. J. 1976, 68, 274-276. [CrossRef]

6. Miele, S.; Grossi, N.; Volterrani, M.; Pardini, G. Il tappeto erboso di Festuca arundinacea sottoposto a diverse altezze di taglio. In Proceedings of the XXXIV Convegno della Società Italiana di Agronomia, Pisa, Italy, 16-21 September 2001; pp. 208-209.

7. Powell, A.J., Jr.; Tapp, L.D. Tall fescue variety evaluations. In Kentucky Turfgrass Research; University of Kentucky, College of Agriculture: Lexington, KY, USA, 1988; pp. 6-12.

8. Reicher, Z.J.; Throssell, C.S. Influence of seeding rate, nitrogen, and mowing height on establishment of turf-type tall fescue. In Agronomy Abstracts; American Society of Agronomy: Madison, WI, USA, 1991; p. 181.

9. Grossi, N.; Volterrani, M.; Magni, S.; Miele, S. Tall fescue turf quality and soccer playing characteristics as affected by mowing height. Acta Hortic. 2004, 661, 319-322. [CrossRef]

10. Burns, R.E. Time of fertilizer application as it affects quality of tall fescue turf. In Proceedings of the 4 th International Turfgrass Research Conference, Guelph, ON, Canada, 19-23 July 1981; Sheard, R.W., Ed.; University of Guelph: Guelph, ON, Canada, 1981; pp. 285-291.

11. Beard, J.B. Turfgrass: Science and Culture; Prentice Hall: Englewood Cliffs, NJ, USA, 1973.

12. Grossi, N.; Fontanelli, M.; Garramone, E.; Peruzzi, A.; Raffaelli, M.; Pirchio, M.; Martelloni, L.; Frasconi, C.; Caturegli, L.; Gaetani, M.; et al. Autonomous Mower Saves Energy and Improves Quality of Tall Fescue Lawn. HortTechnology 2016, 26, 825-830. [CrossRef]

13. Chandler, R.C. Autonomous Agent Navigation Based on Textural Analysis. Ph.D. Thesis, University of Florida, Gainesville, FL, USA, 2003.

14. Ragonese, A.; Marx, J. The applications of sensor technology in the design of the autonomous robotic lawn mower, Paper No. 5094. In Proceedings of the 15th Annual Freshman Engineering Conference, Pittsburgh, PA, USA, 11 April 2015.

15. Etesia. They Mow Every Day, without You. Available online: http://www.etesia.com/en/products/robotetm105.html (accessed on 24 August 2016).

16. Zucchetti. Ambrogio Robot. Available online: http://www.ambrogiorobot.com/en/ambrogiorobot (accessed on 24 August 2016).

17. Husqvarna. Husqvarna Automower 105/310/315/320/330X/420/430X/450X Operator's Manual. Available online: http:/ / www.husqvarna.com/uk/support/manuals-downloads / (accessed on 24 August 2016).

18. Honda. Miimo at a Glance. Available online: http://www.honda.co.uk/lawnandgarden/products/miimo2015/overview.html (accessed on 24 August 2016). 
19. Robomow. Choose Your Best Team Player. Available online: http://robomow.com/en-GB/productcategory/mowers/ (accessed on 24 August 2016).

20. Hicks, R.W.; Hall, E.L. Survey of robot lawn mowers. In Proceedings SPIE 4197, Intelligent Robots and Computer Vision XIX: Algorithms, Techniques, and Active Vision; Society of Photo-Optical Instrumentation Engineers (SPIE): Boston, MA, USA, 2000; pp. 262-269.

21. Brede, D. Turfgrass Maintenance Reduction Handbook: Sports, Lawns, and Golf; John Wiley \& Sons: Hoboken, NJ, USA, 2000.

22. Macolino, S.; Ziliotto, U. The impact of returned grass clippings on the root growth of Tall Fescue. Int. Turfgrass Soc. Res. J. 2005, 10, 976-981.

23. Ferguson, M.; Newell, A.J. Evaluation of the Bigmow Automatic Mower. Belrobotics S. A Project Number TB101281. 2010. Available online: https://www.belrobotics.com/sites/default/files/Bigmow-report-STRIen.pdf (accessed on 24 August 2016).

24. Griggs, S.D.; Horst, G.L. Influence of Mulching Mowers on Tall Fescue Lawns; American Society of Agronomy: Madison, WI, USA, 1980; p. 117.

25. Horst, G.L.; Griggs, S.D.; Rolph, C.C. The Influence of Mulching Mowers on Established Lawns; Progress Report-Texas Agricultural Experiment Station (USA): Beltsville, MD, USA, 1981.

26. Troll, J.; Hurto, K.A. Comparative Turf Response from Conventional and Mulching Rotary Mowers on Kentucky Bluegrass Turf; American Society of Agronomy: Madison, WI, USA, 1981; p. 128.

27. Grossi, N.; Volterrani, M.; Magni, S.; Miele, S. Caratteristiche qualitative del tappeto erboso di Festuca arundinacea Schreb, in funzione della gestione dei residui del taglio. In Proceedings of the XXXV Convegno della Società Italiana di Agronomia, Napoli, Italy, 16-18 September 2003; pp. 307-308.

(C) 2018 by the authors. Licensee MDPI, Basel, Switzerland. This article is an open access article distributed under the terms and conditions of the Creative Commons Attribution (CC BY) license (http:/ / creativecommons.org/licenses/by/4.0/). 